Article - Engineering, Technology and Techniques

\title{
Indoor Air Quality in the Hospital: The Influence of Heating, Ventilating and Conditioning Systems
}

\section{Jelena Božić1}

https://orcid.org/0000-0002-4243-1613

Predrag llić $1{ }^{1, *}$

https://orcid.org/0000-0002-0316-5615

\section{Svetlana ilić ${ }^{1}$}

https://orcid.org/0000-0003-4150-753X

${ }^{1}$ Institute for Protection and Ecology of the Republic of Srpska, Banja Luka, Republic of Srpska, Bosnia and Herzegovina;

Received: 2018.06.12; Accepted: 2019.05.19

*Correspondence: predrag.ilic@institutzei.net; Tel.: +387-51-218322 (P.I.)

\section{HIGHLIGHTS}

- Clean, fresh air is the most important requirement for good indoor air quality.

- Biological contamination of indoor air is mostly caused by bacteria and fungi.

- The number of bacteria and fungi is higher in areas without HVAC systems.

- Early identification of microbiological air quality in hospitals is very important.

Abstract: Clean, fresh air is the most important requirement for good indoor air quality (IAQ) in all buildings, but it is especially important with regard to the environments within hospitals and other healthcare facilities. The literature indicates that buildings with heating, ventilating and air conditioning (HVAC) systems may have an increased risk of sick building syndrome (SBS) and building-related illness (BRI) if they are not well maintained. Microorganisms are brought into hospitals by people, air currents, water, construction materials and equipment. The main objective of this study was to assess the degree of fungal and bacterial contamination in the University Clinical Centre in Banja Luka, which is directly connected to the HVAC system. Airborne bacteria and fungi in the indoor hospital environment were assessed experimentally. Air samples were collected during the winter season. This paper presents the results related to the concentration of microorganisms expressed in colony forming units per cubic metre of air sampled (in CFU $/ \mathrm{m}^{3}$ ) together with the microclimatic parameters temperature and relative humidity. The results of monitoring indicate the effectiveness of HVAC systems in reducing microbiological contamination.

Keywords: indoor air quality; hospital; HVAC system; bacteria; fungi. 


\section{INTRODUCTION}

Indoor environment affects health, productivity and well-being. Indoor air quality (IAQ) is an increasingly important issue for occupational and public health [1]. Microbial incidences and the concentrations of bacteria and fungi are usually higher indoors than outdoors. IAQ is important in all buildings, especially in hospitals and other healthcare facilities. A wide range of factors affect IAQ; the quality of the outdoor air, building construction and materials [2], heating, ventilating and air conditioning (HVAC) systems, temperature, humidity, contaminant sources, occupants and possible pollutant pathways are the basic factors that influence indoor air quality [3]. However, it should be noted that in non-industrial indoor environments, the most important source of airborne bacteria is the presence of humans [4].

A 1984 World Health Organization report suggested that as many as $30 \%$ of new and remodelled buildings worldwide may generate excessive complaints related to indoor air quality [5]. For buildings where occupants experience acute health and comfort effects i.e., symptoms associated with acute discomfort (such as headache; eye, nose or throat irritation; dry cough; dry or itchy skin [6]; dizziness and nausea; difficulty in concentrating; fatigue; and sensitivity to odours), that appear to be linked to the time spent in a building, but no specific illness or cause can be identified [7], the most commonly used term is sick building syndrome (SBS). SBS is not a recognized illness. It is simply a convenient term to describe a particular phenomenon and cannot be diagnosed precisely [8]. In contrast, the term building-related illness $(B R I)$ is used when signs and symptoms of a diagnosable illness are identified [9] and can be attributed directly to airborne building contaminants [5]. The most common causes of both SBS and BRI in hospitals are inadequate ventilation [10], chemical contaminants from both indoor and outdoor sources, and biological contaminants bacteria, moulds, fungi and viruses. All of these factors may act in combination with various symptoms. The symptoms closely related to biological toxins are cough, mucous membrane irritation, chest tightness, fever and muscle aches [11].

Bio-aerosols such as bacterial and fungal cells and their spores are, along with non-biological particles, a part of indoor airborne particulate matter and have been related to health issues of human beings for a long time. Temperature and relative humidity are closely associated with microbial growth. Bio-aerosols contribute to approximately 5 to $34 \%$ of indoor air pollution [12].

Biological contamination of indoor air is mostly caused by bacteria, moulds and yeast. They can be dangerous as pathogenic living cells, but they can also secrete some substances that are harmful to health [13] and are usually classified as natural sources of pollution [14]. Indoor levels of airborne bacteria and fungi can be selected as indicators of a healthy indoor environment [15]. In many environments, including hospitals, clean rooms and pharmaceutical facilities, the presence of bio-aerosols can compromise normal activities [16]. The degree of contamination by fungi in the hospital environment may increase dramatically in combination with various factors, such as the presence of construction activities and a favourable microclimate. Exposure to fungi can cause serious health problems, so it is clearly essential, in the abovementioned risk situations, to evaluate the degree of contamination in various environments and to use those evaluations to determine the risk of infection for patients and staff alike, because the use of air conditioning systems does not provide complete protection against fungi [17].

Fungi usually enter a building through outdoor air intakes of the heating, ventilation and air conditioning system, through doors and windows, and as contaminants on building materials and contents. If elevated moisture conditions exist for a sufficient period of time in a building, fungal growth and sporulation may occur [18]. Fungal flora can be hazardous for health, particularly in the HVAC systems in rooms where they can exacerbate allergies and SBS symptoms [7,19], causing irritation of mucous membranes, poor physical condition, tiredness, headaches, vertigo, decreased concentration, reduced memory and intellectual work ability, dermatosis, respiratory diseases (including asthma), and cancers [13]. Moulds and fungi, or their spores, are a frequent cause of asthma, allergic alveolitis, vasomotor rhinitis and urticaria [20]. Although airborne microorganisms encountered in hospital lobbies 
are apparently harmless to healthy people, they can cause adverse health effects in immunocompromised people [21].

The aim of this paper was to determine the level of airborne bacterial and fungal contamination of various hospital indoor environments, equipped with HVAC systems and with no HVAC systems in the University Clinical Centre of Banja Luka, in the city of Banja Luka, Bosnia and Herzegovina.

\section{MATERIAL AND METHODS}

The subject of this study was testing the presence of bacteria and fungi and microclimatic parameters (temperature and relative humidity) in the University Clinical Centre in Banja Luka, which is the largest and most significant public healthcare institution in the Republic of Srpska. The centre's main activity is the hospital treatment of patients (admission, diagnostic and management) at the secondary and tertiary healthcare levels.

The University Clinical Centre complex consists of three building blocks: Clinical central block, Infectious diseases clinic and Clinic of gynaecology and obstetrics. These are modern multi-story reinforced concrete buildings. The clinical space for the hospital treatment of patients accommodates 24 specialist clinics (admissions, diagnostics and management) with departments in which complete laboratorial, biochemical and immunological diagnostic procedures, as well as whole sets of diagnostic procedures, are provided.

Representative samples for this study were chosen from the following clinics: Clinic of Cardiovascular Diseases, Clinic of Gynaecology and Obstetrics, Pulmonary Clinic, Clinic for Skin and venereal Diseases, Paediatric Clinic, Neurosurgery Clinic, and the Infectious Diseases Clinic. Sampling was conducted in 22 rooms with HVAC and in 13 rooms without HVAC.

\section{Analytical Procedure}

For this research, a portable bio-impactor air sampler Sampl'air ${ }^{\mathrm{TM}}$ Lite, manufactured by BioMérieux S. A, Marcy-l'Étoile, France, for microbial air monitoring based on the principle of air impaction was used. Microorganisms were collected by air aspiration through a grid that was situated a few millimetres above a Petri dish. Viable organisms in the air were impacted on the agar. Airflow was adjusted at $200 \mathrm{l} / \mathrm{min}$ and directed over the surface of a Petri dish containing appropriate solid culture media (trypticase soy agar (TSA) and Sabouraud Dextrose Agar (SDA)).

Before each sampling session, the head of the air sampler was properly sterilized. Thirty-five samples were obtained over 10 days (in February and March 2017).

The microbial concentration for each temporal series was expressed as the mean value of colony-forming units (CFU) per $\mathrm{m}^{3}$ of the air analysed. The most likely number was assumed by using the table of correspondence. In parallel, a correlation was established between the values found and the microclimatic parameters using the portable multifunctional Metrel MI 6401 Poly device with SensorLink PRO and professional PC software. Testing of microclimatic parameters (temperature and relative humidity) was performed according to methods IEC 60751:2008 and CEN - EN 12599.

Estimation of airborne fungi was carried out by growth on agar medium. The sampled plates were incubated at $30-35^{\circ} \mathrm{C}$ for $48 \mathrm{~h}$ in the case of bacterial analysis and at $28-32{ }^{\circ} \mathrm{C}$ for $72 \mathrm{~h}$ in the case of fungal sampling. After the incubation period, colony counting was performed with an EasyCount 2 colony counter with supporting software, and the plates were examined for manual CFU counting.

\section{Statistical analysis}

Statistical data processing, while determining the interdependence and relationship between bacteria and fungi and microclimatic parameters (temperature and relative humidity), were calculated and displayed as frequency polygon charts and box plots. Descriptive statistical parameters, such as the mean, standard deviation, median, minimum and maximum, were applied to the data. Bivariate correlation studies (Spearman's, 
Pearson's and Kendall's correlation coefficient test) were used to evaluate the relationship between the concentration of airborne fungi (as $\mathrm{CFU} / \mathrm{m}^{3}$ ) and microclimatic parameters (relative humidity and temperature). A significance level of a $p$-value $<0.05$ was used. For statistical data processing, while determining interdependence and the relationship between bacteria and fungi and microclimatic parameters, EXCEL, JASP Computer software [22] and Free Statistics Software were used [23].

\section{RESULTS}

The values of the number of bacteria and fungi (in CFU $/ \mathrm{m}^{3}$ ) were measured together with the microclimatic parameters.

As presented in Table 1, the concentrations of bacteria varied and ranged from 30 $\mathrm{CFU} / \mathrm{m}^{3}$ to $6,295 \mathrm{CFU} / \mathrm{m}^{3}$. The maximum fungal concentration was $1,125 \mathrm{CFU} / \mathrm{m}^{3}$, while the minimum was $20 \mathrm{CFU} / \mathrm{m}^{3}$. The average levels of bacteria $\left(587 \mathrm{CFU} / \mathrm{m}^{3}\right)$ and fungi $(308$ $\mathrm{CFU} / \mathrm{m}^{3}$ ) indicated that all hospital rooms were generally contaminated.

Table 1. Statistical summary of bacterial and fungal counts and microclimatic parameters

\begin{tabular}{cccccc}
\hline & $\begin{array}{c}\text { Bacteria } \\
\left(\mathbf{C F U} / \mathbf{m}^{3}\right)\end{array}$ & $\begin{array}{c}\text { Fungi } \\
\left(\mathbf{C F U} / \mathbf{m}^{3}\right)\end{array}$ & $\begin{array}{c}\text { Total } \\
\left(\mathbf{C F U} / \mathbf{m}^{3}\right)\end{array}$ & $\begin{array}{c}\text { Temperature } \\
\left({ }^{\circ} \mathbf{C}\right)\end{array}$ & $\begin{array}{c}\text { Relative } \\
\text { humidity (\%) }\end{array}$ \\
\hline Mean & 587.3 & 308.1 & 895.4 & 23.60 & 40.67 \\
Median & 315.0 & 280.0 & 620.0 & 24.10 & 40.50 \\
Std. & 1069 & 264.5 & 1129 & 1.911 & 6.551 \\
$\begin{array}{c}\text { Deviation } \\
\text { Minimum }\end{array}$ & 30 & & & & \\
Maximum & 6,295 & 1,125 & 6,795 & 27.70 & 29.30 \\
\hline
\end{tabular}

Figure 1 shows a frequency polygon plot of bacteria, fungi and total microorganism concentrations at the University Clinical Centre Banja Luka, where the data are binned into regular intervals. The frequency of the measured values of bacteria, fungi and total microorganisms indicates that the largest number of measured values was $(89 \%$ for bacteria, $100 \%$ for fungi and $71 \%$ for total microorganisms) in the range of 20 to $920 \mathrm{CFU} / \mathrm{m}^{3}$ (Fig. 1), which represents a very high number of microorganisms [23-26].

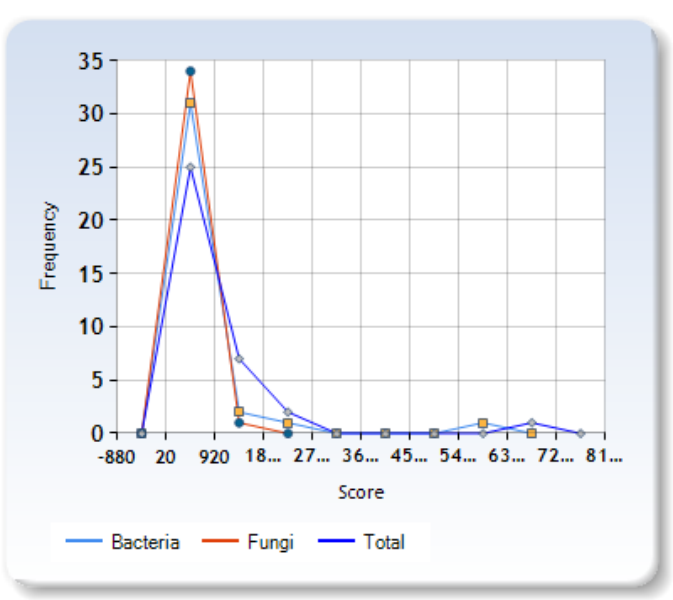

Figure 1. Frequency polygon chart for bacteria and fungi 


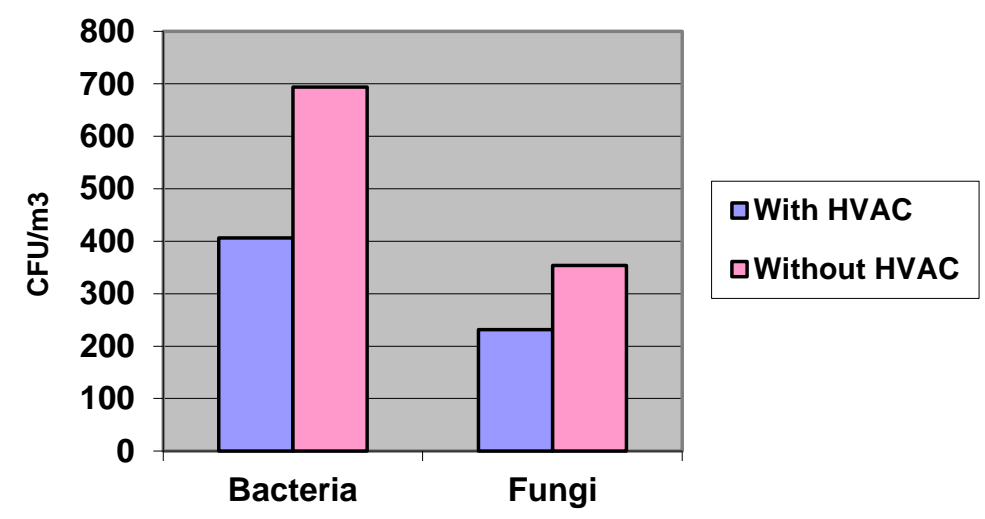

Figure 2. Indoor levels of bacteria and fungi (with and without HVAC)

The number of bacteria and fungi was higher in the areas without HVAC systems (Fig. 2). The statistical summary of bacterial and fungal counts and microclimatic parameters with HVAC indicates that the system is regularly maintained (Tables 2 and 3 ).

Table 2. Statistical summary of bacterial and fungal counts and microclimatic parameters with HVAC

\begin{tabular}{cccccc}
\hline & $\begin{array}{c}\text { Bacteria } \\
\left(\mathbf{C F U} / \mathbf{m}^{3}\right)\end{array}$ & $\begin{array}{c}\text { Fungi } \\
\left(\mathbf{C F U} / \mathbf{m}^{3}\right)\end{array}$ & $\begin{array}{c}\text { Total } \\
\left(\mathbf{C F U} / \mathbf{m}^{3}\right)\end{array}$ & $\begin{array}{c}\text { Temperature } \\
\text { T }\left({ }^{\circ} \mathbf{C}\right)\end{array}$ & $\begin{array}{c}\text { Relative } \\
\text { humidity } \\
\text { RH (\%) }\end{array}$ \\
\hline $\begin{array}{c}\text { Mean } \\
\text { Median }\end{array}$ & 406.5 & 231.2 & 637.7 & 24.23 & 40.04 \\
$\begin{array}{c}\text { Std. } \\
\text { Deviation }\end{array}$ & 310.0 & 105.0 & 440.0 & 24.80 & 40.50 \\
Minimum & 472.9 & 215.5 & 463.0 & 1.522 & 7.076 \\
Maximum & 70.00 & 20.00 & 285.0 & 21.50 & 29.30 \\
\hline
\end{tabular}

Table 3. Statistical summary of bacterial and fungal counts and microclimate parameters without HVAC

\begin{tabular}{cccccc}
\hline & $\begin{array}{c}\text { Bacteria } \\
\left(\mathbf{C F U} / \mathbf{m}^{\mathbf{3}}\right)\end{array}$ & $\begin{array}{c}\text { Fungi } \\
\left(\mathbf{C F U} / \mathbf{m}^{\mathbf{3}}\right)\end{array}$ & $\begin{array}{c}\text { Total } \\
\left(\mathbf{C F U} / \mathbf{m}^{3}\right)\end{array}$ & $\begin{array}{c}\text { Temperature } \\
\left({ }^{\circ} \mathbf{C}\right)\end{array}$ & $\begin{array}{c}\text { Relative } \\
\text { humidity } \\
(\%)\end{array}$ \\
\hline $\begin{array}{c}\text { Mean } \\
\text { Median }\end{array}$ & 694.1 & 353.6 & 1048 & 23.23 & 23.23 \\
$\quad \begin{array}{c}\text { Std. } \\
\text { Deviation }\end{array}$ & 372.5 & 330.0 & 670.0 & 23.95 & 23.95 \\
Minimum & 1301 & 284.4 & 1370 & 2.050 & 2.050 \\
Maximum & 30.00 & 20.00 & 135.0 & 17.70 & 17.70 \\
\hline
\end{tabular}

Figure 3 shows a box plot for the bacterial and fungal concentrations and the relative humidity and temperature measurements. The box plot displays the distribution of data based on the five-number summaries: minimum, first quartile, median, third quartile and maximum.

The relationship between the concentrations of bacteria and fungi $\left(\mathrm{CFU} / \mathrm{m}^{3}\right)$ and relative humidity in the study area was analysed using correlation analysis. The results of the correlation analysis between the concentration of bacteria and fungi and relative humidity are shown in Table 4. 
Bacteria $\left(\mathrm{CFU} / \mathrm{m}^{3}\right)$

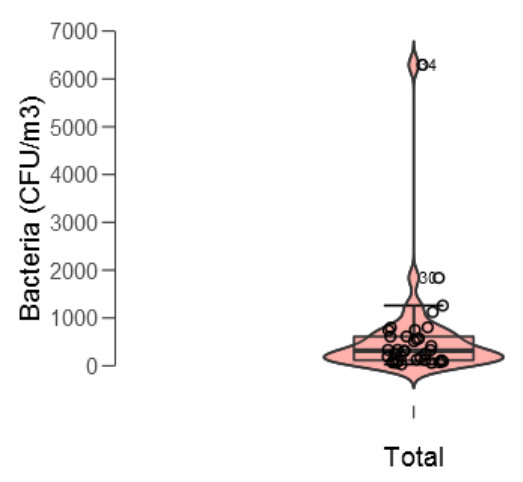

Relative humidity (\%)

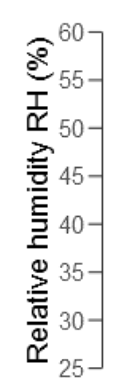

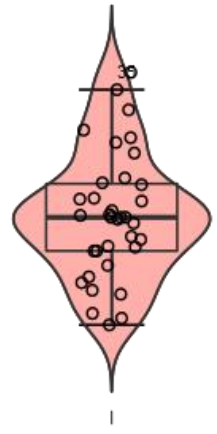

Total
Fungi $\left(\mathrm{CFU} / \mathrm{m}^{3}\right)$
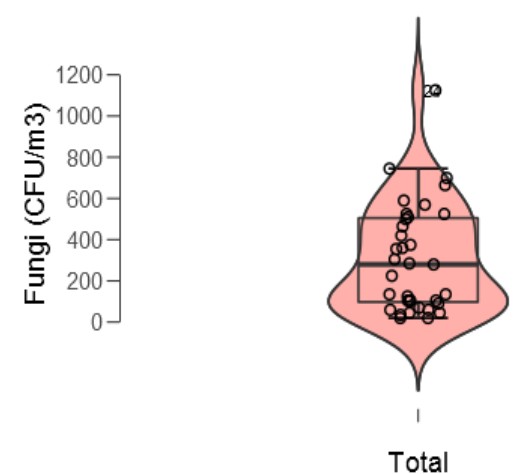

Temperature $\left({ }^{\circ} \mathrm{C}\right)$

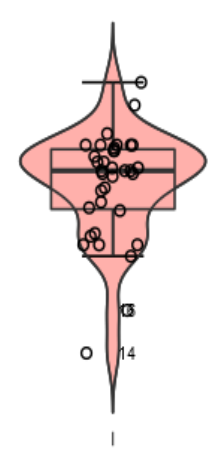

Total

Figure 3. Box plots for bacteria, fungi, relative humidity and temperature

The results of the correlation analysis between the concentration of bacteria and fungi and relative humidity are shown for the level of significance $p<.05$ (Table 4; Fig. 5). The value of $R$ for the correlation between bacteria and relative humidity is 0.399 , and the $\mathrm{p}$-value is 0.018 (Spearman's rank correlation). The association between bacteria and relative humidity is therefore considered statistically significant. The value of $R$ for the correlation between fungal concentration and relative humidity is 0.358 , and the value of $p$ is 0.035 . Again, by normal standards, the association is considered statistically significant. The correlation between these variables was also confirmed by the Kendall rank correlation coefficient. According to Pearson's correlation coefficient, there is a positive correlation ( $r=$ 0.218 ) between the concentrations of bacteria and relative humidity. The $r^{2}$ coefficient of determination value is 0.047 . There is also a positive correlation $(r=0.297)$ between the concentrations of fungi and relative humidity. The $r^{2}$ coefficient of determination value is 0.088. A positive correlation is therefore established, but the relationship between bacteria and fungi and relative humidity is weak. 
Table 4. Correlation between the concentrations of bacteria and fungi $\left(\mathrm{CFU} / \mathrm{m}^{3}\right)$ and relative humidity

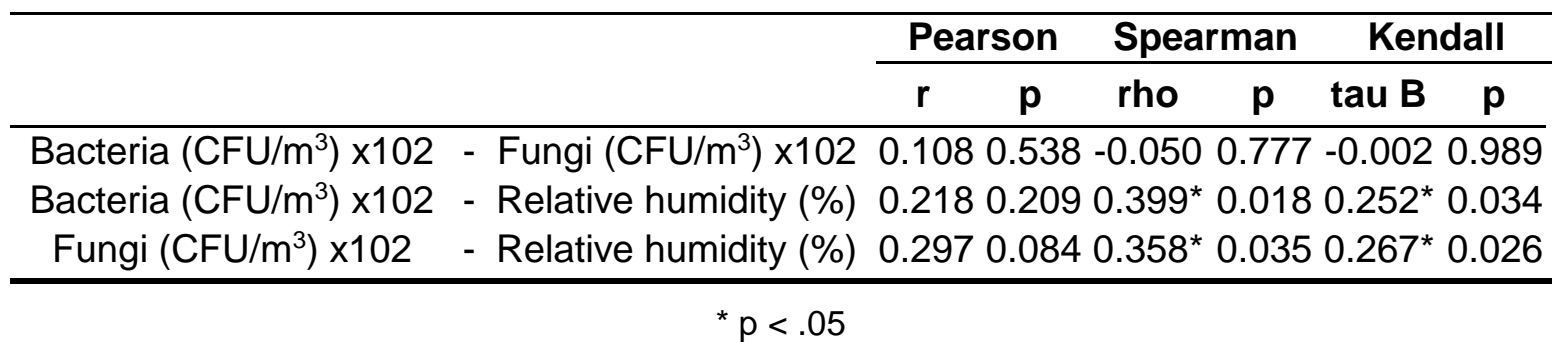

The a analysis of the influence of relative humidity showed that relative humidity had a growth-stimulating impact on the concentration of airborne fungi and bacteria. As relative humidity increase, the concentration of bacteria and fungi increases, and as relative humidity decreases, the concentration of bacteria and fungi decreases (Fig. 4).
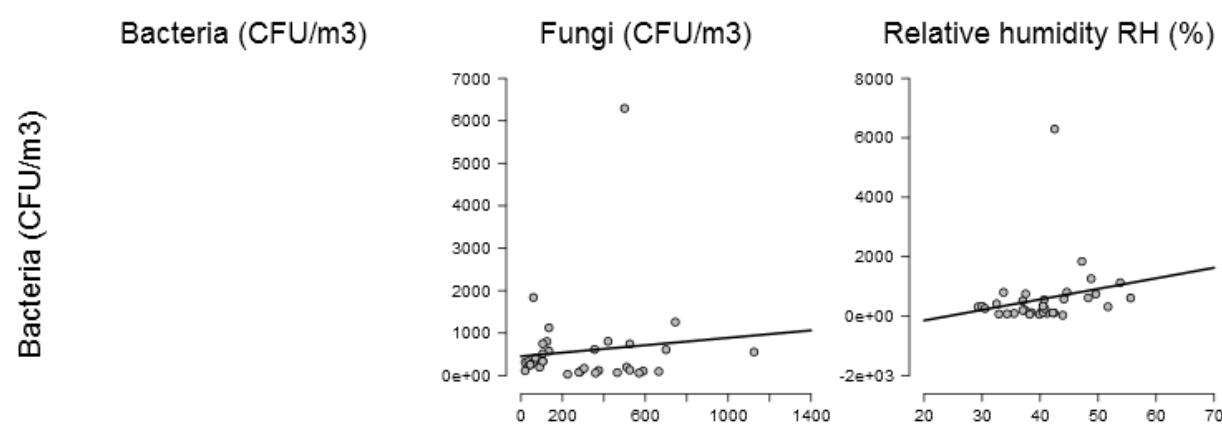

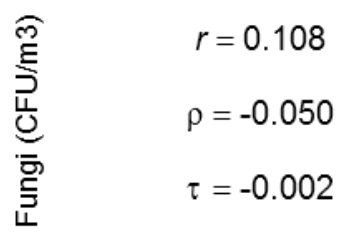

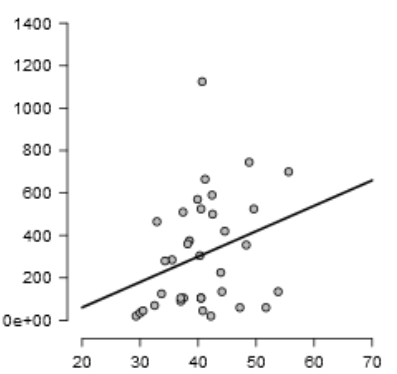

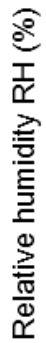

$$
\begin{aligned}
& r=0.218 \\
& \rho=0.399 \\
& \tau=0.252
\end{aligned}
$$$$
r=0.297
$$$$
\rho=0.358
$$$$
\tau=0.267
$$

Figure 4. Correlation between the concentration of bacteria and fungi and relative humidity

\section{DISCUSSION}

Quantitative standards/guidelines range from fewer than $100 \mathrm{CFU} / \mathrm{m}^{3}$ to more than $1,000 \mathrm{CFU} / \mathrm{m}^{3}$ (total fungi) for fungi, as the upper limit for non-contaminated indoor environments, but during this study, the microbial values measured exceeded this threshold at most of the measurement points, and the average value also exceeded this threshold [24].

The European Commission Report established the following limits for bio-aerosols: 0 undetectable, 1-499 CFU $/ \mathrm{m}^{3}$ low, 500-999 CFU $/ \mathrm{m}^{3}$ medium and > $1000 \mathrm{CFU} / \mathrm{m}^{3}$ high [27]; the average value for bacteria in this study was $587 \mathrm{CFU} / \mathrm{m}^{3}$, which indicates a medium level 
of contamination, with high contamination levels measured at many of the sites investigated. The WHO established the guidelines for bio-aerosol counts at $500 \mathrm{CFU} / \mathrm{m}^{3}$ [26] and the American Conference of Governmental Industrial Hygienists (ACGIH) stated that the culturable counts for total bacteria should not exceed $500 \mathrm{CFU} / \mathrm{m}^{3}[27,28]$, which confirms the thesis that there is a high level of contamination in the University Clinical Centre.

Bacteria show higher growth compared to slow-growing fungi. The results of the present study reveal various degrees of contamination in all of the environments examined. Since ventilation is one of the key factors that affect particle deposition rates indoors [29], the hospital is air conditioned for most of the year. Ventilation systems have a significant effect on indoor levels of airborne fungi, with air-handling units reducing, but natural ventilation and fan-coil units increasing the indoor concentrations of airborne fungi [30-33], which was confirmed in this study (Fig. 2). In particular, poorly maintained HVAC systems favour the multiplication of microorganisms that have a negative impact on health but also affect the durability of buildings [7].

The sampling and analysis of airborne microorganisms in indoor air has received attention in recent years. Consistently implemented control strategies decrease the risk of bacterial- and fungal-associated infections among healthcare workers and patients, and immunocompromised people (with immunological disorders), who are at greatest risk of infection caused by airborne microorganisms. Solutions for the improvement of IAQ include pollutant source removal or modification, and maintenance (periodic cleaning and replacement of filters) of HVAC systems. Increasing the ventilation [10] rates of HVAC systems should be designed, at a minimum, to meet ventilation standards in local building codes [5].

Many publications have studied the effect of environmental parameters (e.g., humidity) on the survival of airborne infectious organisms (bacteria and fungi). Our results confirm some of the findings of earlier authors [21,33-36]. Factors such as relative humidity can inactivate free-floating, airborne, infectious organisms [37], which was confirmed in this study.

HVAC systems in hospitals are designed to maintain the indoor air temperature and humidity, to remove contaminated air and to minimize the risk of transmission of airborne pathogens to protect the staff and patients. However, HVAC systems can be an ideal environment for microbial growth. Microorganisms are commonly present in humid, organic environments, but some may also exist under dry conditions. The accumulation of dust and moisture within HVAC systems increases the risk of spreading fungi and bacteria. Clusters of infections caused by Aspergillus spp., Pseudomonas aeruginosa, Staphylococcus aureus and Acinetobacter spp. have been linked to poorly maintained and/or malfunctioning air conditioning systems [38]. Therefore, it is necessary to limit excess humidity and moisture in the HVAC systems to minimize the proliferation and dispersion of fungal spores and waterborne bacteria throughout indoor air [39].

Consistently implemented control strategies decrease the risk of bacterial and fungal infections among healthcare workers and immunocompromised patients, with the greatest risk of infection caused by airborne microorganisms.

Certainly, poor IAQ represents only a portion of the total circumstances leading to infections. The safety and comfort of patients and medical staff are the top priority in all hospitals. Architects and other engineers manage the design and function of hospitals. However, epidemiologists and infection-control professionals with specialized equipment and techniques are required to maintain hospital buildings.

People, air currents, water, construction materials, and equipment bring microorganisms into hospitals. Airborne transmission is the most important route for many microbial pathogens in indoor environments, including hospitals.

The concentration of biological agents inside a building depends not only on the amount of an agent released, which determines the strength of the source but also on the rate of exchange between indoor and outdoor air through ventilation. 


\section{CONCLUSION}

This study provides information on the concentration of microorganisms in the indoor air and describes bacterial and fungal pollution in correlation with HVAC systems inside selected units in the University Clinical Centre in Banja Luka. Variation of the number of bacteria and fungi in the University Clinical Centre in Banja Luka was determined through experimental measurements. Statistical analysis confirmed a direct connection between the number of bacteria and fungi and microclimatic parameters, especially relative humidity. The average levels of bacteria $\left(587 \mathrm{CFU} / \mathrm{m}^{3}\right)$ and fungi $\left(308 \mathrm{CFU} / \mathrm{m}^{3}\right)$ indicated that all hospital rooms were generally contaminated. The indoor bio-aerosol concentration measured during winter is generally significantly lower compared to the measurement during spring.

Microbiological air quality is an important criterion to provide a healthy indoor environment. Early identification and mitigation of pollutants can prevent harm. Since the main sources of airborne bio-aerosols in indoor air are building materials, heating, ventilation, people and their activities, regular air-control measures are crucial for reducing the dissemination of airborne biological particles in hospitals. Therefore, the purpose of this paper was to provide useful information for both healthcare professionals and engineers to minimize the risk of microbiological pathogens in the indoor hospital environment.

These results provide a significant scientific basis for indoor air quality control and help expand the risk prevention programmes for this hospital through a unique and holistic approach to building inspection.

Funding: This research received no external funding.

Acknowledgements: The present study was conducted using equipment from the PSRI Institute for Protection and Ecology of the Republic of Srpska, Banja Luka. We thank the staff of the Institute and University Clinical Centre for support with sampling on-site.

Conflicts of Interest: The authors declare no conflict of interest.

\section{REFERENCES}

1. Bonetta, S.; Bonetta, S.; Mosso, S.; Sampò, S.; Carraro, E. Assessment of microbiological indoor air quality in an Italian office building equipped with an HVAC system. Environ Model Assess 2010, 161(1-4), 473-483.

2. McCunney, R.J. The role of building construction and ventilation in indoor air pollution: Review of a recurring problem. New York State J Med. 1987, 87(4): 203-209.

3. Jaakkola, J.J.; Reinikainen, L.M.; Heinonen, O.P.; Majanen, A.; Seppänen, O. Indoor air quality requirements for healthy office buildings: recommendations based on an epidemiologic study. Environ Int. 1991, 17(4): 371-378.

4. Stetzenbach, L.D. Introduction to aerobiology. In Manual of Environmental Microbiology, Third Edition. Washington D.C.: American Society of Microbiology 2007, p. 925-938.

5. U.S. Environmental Protection Agency (EPA). Office of Air and Radiation. Indoor Air Facts No. 4: Sick Building Syndrome. Revised 2010. Available from: https://www.epa.gov/sites/production/files/2014-08/documents/sick_building_factsheet.pdf

6. Stenerg, B.; Mild, K.H.; Sandström, M.; Sundell, J.; Wall, S. A prevalence study of the sick building syndrome (SBS) and facial skin symptoms in office workers. Indoor Air 1993, 3(2): 71-81.

7. Božić, J. Working Environment and Sick Building Syndrome. In: Proceedings of the Protection and occupational health and environmental protection, Conference. PSI Institute for protection and ecology of the Republic of Srpska; Banja Luka, Bosnia and Herzegovina, 2009. 39-47.

8. Finnegan, M.J.; Pickering, C.A.; Burge, P.S. The sick building syndrome: prevalence studies. Brit Med J. 1984, 289(6458): 1573-1575.

9. Menzies, D.; Bourbeau, J. Building-related illnesses. New Engl J Med. 1997, 337(21): 1524-1531.

10. Jaakkola, J.J.; Miettinen, P. Ventilation rate in office buildings and sick building syndrome. Occup Environ Med. 1995, 52(11): 709-714. 
11. Vanderstraeten, P; Muylle, E; Verduyn, G. Indoor air quality in a large hospital building. Indoor Air 1984, 4: 335-41.

12. Heikkienen, M.S.A.; Hjelmroos-Koski, M.K.; Haggblom, M.M.; Macher, J.M. Bioaerosols. In: Ruzer LS, Harley NH, Editors. Aerosols Handbook. Boca Raton: CRC Press; 2005, 291-342.

13. Stryjakowska-Sekulska, M.; Piotraszewska-Pajak, A.; Szyszka, A.; Nowicki, M.; Filipiak, M. Microbiological quality of indoor air in university rooms. Pol J Environ Stud. 2007; 16(4): 623.

14. Ilić, P.; Marković, S.; Janjuš, Z. History and sources of air pollution. Skup 2012, 4(2):19-31

15. Wong LT, Mui KW, Hui PS, Chan WY, Law AKY. Thermal environmental interference with airborne bacteria and fungi levels in air-conditioned offices. Indoor Built Environ. 2008, 17(2), 122-127.

16. Yassin, M.F.; Almouqatea, S. Assessment of airborne bacteria and fungi in an indoor and outdoor environment. Int J Environ SciTe. 2010, 7(3): 535-544.

17. Perdelli, F.; Cristina, M.L.; Sartini, M.; Spagnolo, A.M.; Dallera, M.; Ottria, G.; Orlando, P. Fungal contamination in hospital environments. Infect ContHosp Ep. 2006, 27(1), 44-47.

18. Shelton, B.G.; Kirkland, K.H.; Flanders, W.D.; Morris, G.K. Profiles of airborne fungi in buildings and outdoor environments in the United States. Appl environ microb. 2002, 68(4): 1743-1753.

19. Seppänen, O.; Fisk, W. Association of ventilation system type with SBS symptoms in office workers. Indoor Air. 2002, 12(2): 98-112.

20. Ilić, P. Pollution and control of air quality in the function of environment protection. Independent University, Banja Luka; 2015.

21. Park, D.U.; Yeom, J.K.; Lee, W.J.; Lee, K.M. Assessment of the levels of airborne bacteria, gram-negative bacteria, and fungi in hospital lobbies. Int J Env Res Pub He. 2013, 10(2): 541-555.

22. JASP Team (2017). JASP (Version 0.8.5.1) [Computer software].

23. Wessa, P. (2018). Free Statistics Software, Office for Research Development and Education, version 1.2.1, URL https://www.wessa.net/

24. Rao, C.Y.; Burge, H.A.; Chang, J.C. Review of quantitative standards and guidelines for fungi in indoor air. J Air Waste Manage. 1996, 46(9): 899-908.

25. CEC Report No. 12: Biological particles in indoor environments. Luxembourg: Commission of the European Communities. 1994.

26. World Health Organization (WHO) Indoor Air quality: Biological Contaminants. European Series. No. 31, Copenhagen: WHO Regional Publication; 1990.

27. Jensen, P.A.; Schafer, M.P. Sampling and characterization of bioaerosols. NIOSH manual of analytical methods. 1998, 1(15): 82-112.

28. Katiyar, V. Assessment of indoor air micro-flora in selected schools. Adv. Environ. Res.2013, 2(1), 61-80.

29. Jamriska, M. Effect of ventilation and filtration on submicrometer particles in an indoor environment. Indoor Air. 2000, 10 (1): 19-26.

30. Burge, H.A.; Pierson, D.L.; Groves, T.O.; Strawn, K.F.; Mishra, S.K. Dynamics of airborne fungal populations in a large office building. CurrMicrobiol. 2000, 40(1): 10-16.

31. Wu, P.C.; Li, Y.Y.; Chiang, C.M.; Huang, C.Y.; Lee, C.C.; Li, F.C.; Su, H.J. Changing microbial concentrations are associated with ventilation performance in Taiwan's airconditioned office buildings. Indoor Air. 2005, 15(1): 19-26.

32. Maclntosh, D.L.; Brightman, H.S.; Baker, B.J.; Myatt, T.A.; Stewart, J.H.; McCarthy, J.F. Airborne fungal spores in a cross-sectional study of office buildings. J Occup Environ Hyg. 2006, 3(7): 379-389.

33. Augustowska, M.; Dutkiewicz, J. Variability of airborne microflora in a hospital ward within a period of one year. Ann Agr Env Med. 2006, 13(1): 99-106.

34. Caggiano, G.; Napoli, C.; Coretti, C.; Lovero, G.; Scarafile, G.; De Giglio, O.; Montagna, M.T. Mold contamination in a controlled hospital environment: a 3-year surveillance in southern Italy. BMC Infect Dis. 2014, 14(1): 595-599.

35. El-Sharkawy, M.F., Noweir, M.E. Indoor air quality levels in a University Hospital in the Eastern Province of Saudi Arabia. J Family Community Med. 2014, 21(1): 39-47. 
36. Ramos, T.; Dedesko, S.; Siegel, J.A.; Gilbert, J.A. Stephens B. Spatial and temporal variations in indoor environmental conditions, human occupancy, and operational characteristics in a new hospital building. PLoS One. 2015, 10(3): e0118207.

37. Tang, J.W. The effect of environmental parameters on the survival of airborne infectious agents. J. R. Soc. Interface. 2009, 6, S737-S746

38. Anderson, K.; Morris, G.; Kennedy, H.; Croall, J.; Michie, J.; Richardson, M.D.; Gibson, B. Aspergillosis in immunocompromised paediatric patients: associations with building hygiene, design, and indoor air. Thorax. 1996, 51(3): 256-261.

39. Bearg, D.W. HVAC systems. Ch. 7. In: J. D., Samet JM, McCarthy JF, editors. Indoor Air Quality Handbook. New York: McGraw-Hill; 2001. p. 1-7. under the terms and conditions of the Creative Commons Attribution (CC BY NC) license (https://creativecommons.org/licenses/by-nc/4.0/). 